Obituary

\title{
Listening to the Pacific: In remembrance of Terry Crowley
}

\author{
NICHOLAS EVANS
}

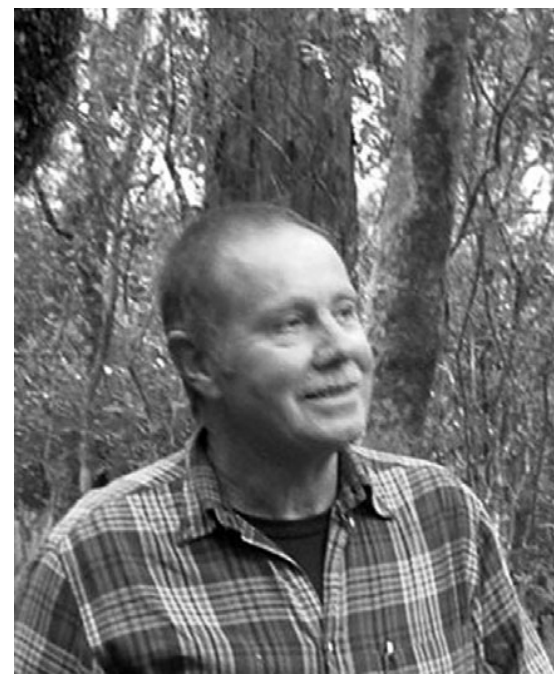

Terry Crowley relaxing in the bush, May 2004 (photo courtesy of Janet Holmes)

The Antipodean linguistics community lost one of its most versatile, productive, and humane members this January with the unexpected death of Terry Crowley, professor of linguistics at Waikato University in Hamilton, New Zealand, at the early age of 51 . The 21 books and over 70 journal articles he produced include grammars of seven languages from two language families (Australian, Oceanic/Austronesian) and two English-based Pacific creoles (Bislama, the main lingua franca of Vanuatu, and Cape York creole, of Queensland), all based on his own fieldwork, dictionaries, textbooks in both historical and descriptive linguistics, and a recent book on the typology of serial verbs in Oceanic languages, in addition to numerous articles. His work in descriptive typology was thus given an extraordinary breadth by being embedded in a range of activities that included long-term fieldwork, contributions to the development and codification of one of the few creoles to be adopted as a national language (Bislama), and the training of students in descriptive and historical work, particularly of students from Pacific nations who were often the first generation of their culture to receive higher education.

Born in Billericay, Essex on April 1, 1953, Terry emigrated with his family to Australia where he went to a rural school near Shepparton, Victoria. 
Against the grain of footie and farming, he was already clear enough about his direction from an early age to set out his ambition to "become a philologist" in a career counselling session at high school. In 1971 he took up an Asian Studies Scholarship at the Australian National University in Canberra. Unusually for the time, the fledgling Bachelor of Asian Studies degree encouraged students to take linguistics alongside their nominated language major, which in Terry's case was Bahasa Indonesia. Bob Dixon's newly established Department of Linguistics offered students the chance to undertake original descriptive and historical work from early in their degree, and as a third-year student Terry made his debut in Australianist studies with his brilliant demonstration that the Nganyaywana (Anewan) language of northern New South Wales, then believed to be one of the few languages unrelated to other members of the Australian family, could in fact be related to its neighbours if one postulated a series of radical phonological changes involving the loss of initial consonants. This was soon followed by his grammar of Bandjalang, another language of northern New South Wales, on the basis of summer fieldwork leading to his fourthyear honours thesis, which won him a University Medal. The subsequentlypublished version (Crowley 1978) still stands as one of the best descriptions of a language of south-eastern Australia, where language death has meant that such work would be impossible thirty years later.

After completing his Honours degree, he worked for a year as a research assistant for Bob Dixon, carrying out fieldwork on a number of other languages in Cape York, all then down to their last few speakers. A possibly apocryphal story has it that he petitioned to return to Canberra following a night when a large snake entered his sleeping bag, but was told to stay in the field until he got the job finished. Whatever the case, this year produced grammatical sketches of two phonetically-difficult Australian languages, Uradhi (Crowley 1983) and Anguthimri (Crowley 1981), the latter containing one of the largest phoneme inventories in Australia. It was to lead as well to one of the first descriptions of an Australian Creole, based on the contact language used in the Torres Strait (Crowley \& Rigsby 1979).

For his doctoral research, still at the ANU, he turned to a new field area, Vanuatu, undertaking a grammatical study of Paamese. Vanuatu and its languages were to become his lifelong love. Its extraordinary linguistic diversity, married with a vibrant maintenance of traditional language and custom, contrasted starkly with the discouraging field conditions he had worked under in Australia. He liked to point out that with over a hundred languages for a population of 195,000 it is the most linguistically-diverse nation in the world, and in fact it was difficult to get an accurate overall picture of this until the publication of his survey and bibliography with John Lynch in 2001. Besides producing one of the first modern book-length grammars of a Vanuatu language for his doctoral thesis, later published as Crowley (1982), he embarked on the path of 
learning the rapidly-developing national creole Bislama. Initially, as he points out in the introduction to his recent reference grammar of Bislama, he had had no intention of studying Bislama for itself, but merely learned it as a means of gaining access to Paamese and other local languages. Nonetheless, this was eventually to lead to his major dictionary (Crowley 1990a, 1995a, second edition 2003) and reference grammar (Crowley 2004) as well as his impeccable account of its historical development (Crowley 1990b). I cannot think of another case, anywhere in the world, where the author of the definitive grammar and dictionary of a creole has also published equally detailed grammars and dictionaries of three traditional languages of the region. This background lends Crowley's Bislama work a particularly profound perspective on possible substrate influences. Characteristically, a precursor of his grammar appeared first in a Bislama version (Crowley 1987a), coining new Bislama grammatical terminology as it went.

His professional appointments after completing his doctorate took him first to Papua New Guinea, where from 1979 to 1983 he was a lecturer in the Department of Language at the University of PNG in Port Moresby, then to Vanuatu, where from 1983 to 1990 he was director of the Pacific Languages Unit of the University of the South Pacific, in Port Vila, and finally to Hamilton, New Zealand, where from 1991 until his death he taught in the Department of General and Applied Linguistics at the University of Waikato, obtaining a full professorship in 2003. Throughout this period he maintained an astonishingly productive combination of teaching, research, and public engagement with language-related issues. These ranged from community programmes for language maintenance, problems of vernacular education, including the complex relation between local vernaculars, emerging national creoles and English in the bi- or multilingual school (see, e.g., Crowley 2000a), national-level language planning in Pacific nations, and the development and codification of Bislama as a national language. The latter is in the paradoxical position that despite being the only creole to have a higher constitutional status than the former colonial languages of the country, it has no formal place in the national education system.

He also wrote thoughtfully about medical and social debates surrounding the use of the Pacific drink kava (Crowley 1991/92, 1992a). As was mentioned in the front-page obituary for him in the Vanuatu Daily Post, he was "a great supporter of the national drink", both in practice and in scholarly research, as shown by the title of one of his historical linguistic articles in Wörter und Sachen vein: 'proto who drank kava?' (Crowley 1994). Otherwise, his life was spartan: his day would begin at $5.00 \mathrm{am}$, he would be at his desk an hour later, finishing about $5.00 \mathrm{pm}$, go for a run, and be in bed by $8.30 \mathrm{pm}$. Though modest and unassertive in his personal style, he was capable of taking a feisty stand in scholarly debate, as witnessed by his astute evaluation of historical linguistic 
studies of Australian languages (Crowley 1997) or his bracing review - almost as a lone critical voice among widespread praise - of R. M. W. Dixon's 1997 Rise and Fall of Languages (Crowley 1999a).

At the same time, Terry was unstinting in his efforts to make the results of his research available to the speech communities of the Pacific, and frequently used Bislama as a medium to do this. The clarity and freshness of his textbook Historical Linguistics, which breaks with tradition in that field by shifting the burden of exemplification from Indo-European to Austronesian and other languages of the Pacific, while at the same time managing to present the essence of the comparative method without its centuries-old accretions of arcane terminology, owes much to the distilling effect of his many public lectures and presentations in Bislama. Appearing originally as course notes at the Universities of Papua New Guinea and the South Pacific (Crowley 1987b), it was picked up as a revised edition by Oxford University Press in 1992 (Crowley 1992b) and by 1997 (Crowley 1997b) had reached its third edition: thus did a book that had originally been intended as a course book for students at the University of South Pacific become one of the classic general textbooks in historical linguistics. A 1995 textbook on descriptive linguistics, which he wrote with John Lynch, Jeff Siegel, and Julie Piau, is comparably clear and fresh, though unfortunately less well-known than his historical textbook.

Terry's kindness and generosity did much to reciprocate the hospitality he received in remote villages where he would typically spend three months a year living like a ni-Vanuatu on village food. He frequently supported Pacific students studying in his home, often as a guest in his Hamilton house. In one case Edward Nalial, who stayed with him as a guest while studying law in Waikato, encouraged him to study the languages of Erromango, leading to grammars of Sye (1998) and Ura (1999b) and a dictionary (2000b) of Sye.

At the time of his death, Terry was launched into a major project, involving himself and two other New Zealand linguists and supported by the Marsden Fund, to study the languages of Malekula, one of the most linguistically-diverse and unknown islands of the archipelago, where many languages now hang by a thread following the diseases and depopulations of the early colonial period. His untimely death in the middle of this new project is a tragedy. Despite occasional bouts of malaria that he always regarded as occupational hazards of a fieldworker - the most recent leading to a period of hospitalization in November last year - he was in good health.

Terry regarded himself as a general linguist, rather than a practitioner of any particular subdiscipline, be it historical linguistics, descriptive linguistics, Creolistics, sociolinguistics, or typology - he moved constantly between these fields, did not see clear boundaries between them, and his work in one area was always enriched by his insights from others. My own evaluation of what he brought to typology would dwell on three particular types of contribution. 
First is his incredible descriptive legacy, providing the raw materials on which any typological work must be based, and founded on original fieldwork on languages about which little or nothing was known: grammars of three Australian Aboriginal languages (Bandjalang, Anguthimri, and Uradhi), three Oceanic languages of Vanuatu (Paamese, Ura, and Sye), and two creoles, one reflecting the contact between English and Australian languages and one the contact between English and Oceanic languages; for three of these languages (Paamese, Sye, and Bislama) he also produced major dictionaries. In addition to this he assembled shorter descriptive materials on a wide range of other languages, most recently in the monumental The Oceanic Languages (2002) that he co-edited with John Lynch and Malcolm Ross.

Second was his work directly addressing typological questions, particularly those chestnuts of Oceanic descriptive puzzlement, possession classifiers (e.g., Crowley 1995b) and serial verbs, where his seminal paper on Paamese verbs (Crowley 1987c) was more recently followed up with a masterly synthesis in his 2002 book Serial Verbs in Oceanic: A Descriptive Typology.

Thirdly - and this is something of a leitmotiv in many parts of his work, though never assembled into an expressly-titled synthesis - was his concern for the way structure is reshaped through language contact and rebuilt in emergent creoles from the shreds of pidginized materials under the convergent influence of more complex traditional languages, against a backdrop of traditional multilingualism. This fed through into the way he interwove materials from creoles and more traditional languages into his typological work: a recent review of his Serial Verbs book begins: "How refreshing to read a major typological study of Oceanic languages and find so little reference to Fijian and Polynesian languages - and a whole chapter devoted to Melanesian Pidgin!" (Bradshaw 2004).

His premature death has left a tumble of unfinished work across a characteristically wide range of interests, and robbed the community of linguists, his family, and the many people whose lives he touched in the towns and villages of Vanuatu, of a loved and respected friend and practitioner, with an unstinting commitment to a linguistics that would engage with the challenges and problems faced by the speakers of the languages he studied, but whose unassuming manner gave no indication of the breadth and depth of his influence on the field. We mourn his passing.

Received: 2 March 2005

University of Melbourne

Correspondence address: Department of Linguistics and Applied Linguistics, University of Melbourne, Parkville, Victoria 3010, Australia; e-mail: nrde@unimelb.edu.au 


\section{Nicholas Evans}

\section{References}

Bradshaw, Joel (2004). Review of T. Crowley, Serial Verbs in Oceanic: A Descriptive Typology. Oceanic Linguistics 43: 264-268.

Crowley, Terry (1976). Phonological change in New England. In R. M. W. Dixon (ed.), Grammatical Categories in Australian Languages, 19-50. Canberra: Australian Institute of Aboriginal Studies.

- (1978). The Middle Clarence Dialects of Bandjalang. Canberra: Australian Institute of Aboriginal Studies.

- (1981). The Mpakwithi dialect of Anguthmri. In R. M. W. Dixon \& Barry J. Blake (eds.), Handbook of Australian Languages, Vol. 2, 146-194. Canberra: ANU Press.

- (1982). The Paamese Language of Vanuatu (Pacific Linguistics, B-87). Canberra: Australian National University.

- (1983). Uradhi. In R. M. W. Dixon \& Barry J. Blake (eds.), Handbook of Australian Languages, Vol. 3, 306-428. Canberra: ANU Press.

- (1987a). Grama blong Bislama. Suva: Extension Services (University of the South Pacific).

- (1987b). An Introduction to Historical Linguistics. Port Moresby and Suva: University of Papua New Guinea Press and Institute of Pacific Studies (University of the South Pacific).

- (1987c). Serial verbs in Paamese. Studies in Language 11: 35-84.

- (1990a). An Illustrated Bislama-English and English-Bislama Dictionary. Vila (Vanuatu): Pacific Languages Unit and Vanuatu Extension Centre (University of the South Pacific).

- (1990b). Beach-la-Mar to Bislama: The Emergence of a National Language in Vanuatu. Oxford: Clarendon.

- (1991/92). Review of R. Brunton, The Abandoned Narcotic: Kava and Cultural Stability in Melanesia. Pacific Affairs 64: 608-609.

- (1992a). Review of G. McCall \& J. Prescott, Kava: Use and Abuse in Australia and the South Pacific. Journal of the Polynesian Society 101: 193-194.

- (1992b). An Introduction to Historical Linguistics. Second Edition. Auckland: Oxford University Press.

- (1994). Proto who drank kava? In Andrew K. Pawley \& Malcolm D. Ross (eds.), Austronesian Terminologies: Continuity and Change (Pacific Linguistics, C-127), 87-100. Canberra: Australian National University.

- (1995a). A New Bislama Dictionary. Suva: Institute of Pacific Studies and Pacific Languages Unit (University of the South Pacific).

- (1995b). Inalienable possession in Paamese grammar. In Hilary Chappell \& William McGregor (eds.), The Grammar of Inalienability: A Typological Perspective on Body Parts and the Part-whole Relation, 385-434. Berlin: Mouton de Gruyter.

- (1997a). Chipping away at the past: A northern New South Wales perspective. In Patrick McConvell \& Nicholas Evans (eds.), Archaeology and Linguistics: Aboriginal Australia in Global Perspective, 275-295. Melbourne: Oxford University Press.

- (1997b). An Introduction to Historical Linguistics. Third Edition. Melbourne: Oxford University Press.

- (1998). An Erromangan (Sye) Grammar. Honolulu: University of Hawai'i Press.

- (1999a). Review of R. M. W. Dixon, The Rise and Fall of Languages. Australian Journal of Linguistics 19: 109-115.

- (1999b). Ura: A Disappearing Language of Southern Vanuatu (Pacific Linguistics, C-156). Canberra: Australian National University.

- (2000a). Vernaculars in Education in Vanuatu. Report prepared for World Bank and Vanuatu Ministry of Education, Youth and Sport. Hamilton (New Zealand): Department of General and Applied Linguistics (University of Waikato).

- (2000b). An Erromangan (Sye) Dictionary (Pacific Linguistics, 508). Canberra: Australian National University.

- (2002). Serial Verbs in Oceanic: A Descriptive Typology. Oxford: Oxford University Press. 
- (2003). A New Bislama Dictionary. Second Edition. Suva: Institute of Pacific Studies (University of the South Pacific).

- (2004). Bislama Reference Grammar. Honolulu: University of Hawai’i Press.

Crowley, Terry, John Lynch, Jeff Siegel, \& Julie Piau (1995). The Design of Language: An Introduction to Descriptive Linguistics. Auckland: Longman Paul.

Crowley, Terry \& Bruce Rigsby (1979). Cape York Creole. In Timothy Shopen (ed.), Languages and their Status, 153-207. Cambridge, Mass.: Winthrop.

Lynch, John \& Terry Crowley (2001). Languages of Vanuatu: A New Survey and Bibliography (Pacific Linguistics, 517). Canberra: Australian National University.

Lynch, John, Malcolm Ross, \& Terry Crowley (2002). The Oceanic Languages. London: Curzon Press. 